Copyright ( $) 2016$ SCAD Independent

All Rights Reserved

Printed in the Indonesia
Jurnal Ilmiah Peuradeun Vol. 4, No. 3, Sep 2016

\title{
CHALLENGE LEARNING FOR TEACHERS IN RURAL GWERU ZIMBABWE
}

\author{
Gladwin Bhebhe \& Matiya Mugurani \\ Department of Educational Foundations, Management and Curriculum Studies, \\ Midlands State University Zimbabwe \\ Email:gwin_bhebhe@yahoo.com
}

Received: Sep 12, 2015

Accepted: Feb 25, 2016

Published: Sep 28, 2016

Article Url: https:/ /journal.scadindependent.org/index.php/jipeuradeun/article/view/104

\begin{abstract}
The study established that rural day secondary school science teachers face a number of challenges, including inadequate teaching and learning materials, students' negative attitudes towards science, conflicts between students' home background and school science, and absence of science teachers' associations. These challenges could have a direct impact on the teaching and learning of science in rural day secondary schools. The opening of rural day secondary schools in Zimbabwe was a great challenge in terms of providing science education to all students because the newly opened secondary schools did not have conventional laboratories and equipment that would facilitate the teaching and learning of science. This study sought to find out the challenges faced by rural day secondary school science teachers in Gweru district of Zimbabwe and propose a way forward. Questionnaires, interviews and observations were used to collect data pertaining to the challenges that were faced by the teachers.
\end{abstract}

Keywords: Challenges, Teachers, Rural Schools, Gweru Zimbabwe 


\section{A. Introduction}

The attainment of Zimbabwe's independence in April 1980 saw an unprecedented expansion of education at all levels. The number of secondary schools increased and the majority of secondary schools were rural day schools. This massive expansion of education attracted so much international attention that Zimbabwe acquired the reputation of Africa's "flagship" in the development of education in Eastern and Southern Africa (Ross, 1998).

The opening of rural day secondary schools in Zimbabwe was a great challenge in terms of providing science education to all students because the newly opened secondary schools did not have conventional laboratories and equipment that would facilitate the teaching and learning of science. In the light of these developments, the Zimbabwe Secondary School Science Project, generally known as Zim-Sci was introduced. The Zim-Sci project was the brainchild of Allan Dock, who was then a Lecturer at the Science Education Centre of the University of Zimbabwe, Harare. The Zim-Sci team developed the following: (i), students' study guides that were meant to address and teach the students directly; (ii), detailed teachers' guides that were targeted at untrained teachers; and (iii), low cost experimental kits that did not require the use of conventional laboratories. The Zim-Sci project was well suited for the rural day secondary schools since it enabled science to be accessible to all students.

However, in the 1990's, there was evidence that science teaching and learning in rural day secondary schools were losing the gains made in the 1980's (Hungwe, 1994). To that effect, Nziramasanga (1999) noted that, generally, secondary schools were under-resourced. Textbooks were in short supply and most schools did not have laboratories. The Commission (Nziramasanga, 1999) also noted that there was inadequate equipment in the few schools where laboratories had been built.

Effective science teaching and learning would entail providing both the teachers and students with an enabling pedagogical learning environment. The following factors would promote effective science teaching and learning: a well equipped laboratory/science room, trained 
teachers, use of progressive teaching methods that emphasise a "handson" and "minds-on approach," relevant teaching and learning resources, and positive attitudes towards science teaching and learning by both teachers and students (Hodson, 1992)

Most of the rural day secondary schools in Zimbabwe offer the Integrated Science syllabus. The syllabus is designed to meet the needs of candidates whose formal study of science may cease at the end of ' $O$ ' level. The syllabus emphasizes a practical and investigative approach to teaching science.

The objectives of the Integrated Science syllabus indicate that secondary schools should provide students with opportunities to develop their experimental skills in a laboratory or science room. In Zimbabwe, the Ministry of Education pays per capita grants to each school to purchase teaching and learning materials and equipment. However, the amount per pupil is not adequate to cover all the basic requirements, to the extent that schools have to supplement this grant through levying parents. Unfortunately, most of the parents in rural areas are peasant farmers and, therefore, could not afford to pay the high levies needed to buy expensive equipment and chemicals that are required for the effective teaching and learning of science. Since the Zim-Sci project was the lifeline of rural day secondary schools, its subsequent "death" could have led to science teachers and students facing many challenges as evidenced by an average science pass rate of as low as $10 \%$.

The purpose of the study was to determine the availability of science equipment and consumables in rural day secondary schools in Gweru district of Zimbabwe; and to elicit the challenges faced by science teachers teaching Integrated Science syllabus 5006 in the same schools.

\section{B. Method}

The target population for this study was 49 science teachers teaching Integrated Science syllabus (5006) in all the 19 rural day secondary schools in Gweru district of Zimbabwe. However, only 44 teachers who were available at the time of the study participated in the 
study. The researcher collected data on the availability of science equipment and consumables in all the 19 rural day secondary schools using a checklist schedule. Data on the availability of science equipment and consumables was also collected from 10 urban secondary schools for comparison purposes. Data were also collected from 44 science teachers using an open-ended questionnaire. The questionnaire elicited the challenges faced by the science teachers when teaching integrated science syllabus (5006). Focus group interviews with the science teachers were also conducted in an attempt to gain more insight into the challenges they were facing.

\section{Research Finding and Discussion}

\section{Biographical data}

The biographical data collected from the respondents showed that of the 44 teachers, $32(72.7 \%)$, were holders of a Certificate or Diploma in Education, eight $(18.2 \%)$ were University science graduates with a teaching qualification and the remaining four $(9.1 \%)$ were untrained. Their teaching experience ranged from 1 to 12 years.

\section{Availability of science equipment/apparatus in rural day and urban secondary schools}

Table 1 shows data on availability of science equipment/apparatus in rural day and urban secondary schools. The frequencies shown in Table 1 indicate the number of schools that had the listed science equipment/apparatus, and not the quantities of the items.

Table 1 shows that rural day secondary schools had problems in acquiring relatively expensive equipment such as Bunsen burners, $\mathrm{pH}$ meters, photometers, electric motors, bar breakers, triple beam balances, gas cylinders, solar panels, vacuum flasks and bimetallic strips. However, urban secondary schools were relatively better equipped than rural day secondary schools with regards to the same items as shown by a mean of $62.1 \%$ for urban secondary schools as compared to rural day secondary schools with a mean of $29.9 \%$. Since the $t$ calculated of 3.79 was greater than $t$ critical of 2.00 at $p \leq 0.05$, it was 
concluded that there was a significant difference in the availability of science equipment between rural secondary schools and urban secondary schools.

Table 1. Availability of equipment/apparatus in rural day and urban secondary schools

\begin{tabular}{|c|c|c|c|c|}
\hline \multirow[t]{2}{*}{ Type of equipment } & \multicolumn{2}{|c|}{ Rural schools $(\mathrm{n}=19)$} & \multicolumn{2}{|c|}{ Urban schools $(n=10)$} \\
\hline & Frequency & $\%$ & Frequency & $\%$ \\
\hline Conventional science & 2 & 10.5 & 9 & 90.0 \\
\hline laboratory & & & & \\
\hline $\begin{array}{l}\text { Ordinary classroom used } \\
\text { for science teaching }\end{array}$ & 8 & 42.1 & 1 & 10.0 \\
\hline Bunsen burners & 0 & 0 & 6 & 60.0 \\
\hline Spirit burners & 10 & 52.6 & 4 & 40.0 \\
\hline Test tubes/boiling tubes & 11 & 57.9 & 10 & 100.0 \\
\hline $\mathrm{pH}$ meters & 0 & 0 & 2 & 20.0 \\
\hline Boiling tins/cans & 15 & 78.9 & 1 & 10.0 \\
\hline Glass evaporating dishes & 4 & 21.1 & 6 & 60.0 \\
\hline Potometers & 0 & 0 & 1 & 10.0 \\
\hline Electric bulbs & 8 & 42.1 & 10 & 100.0 \\
\hline Measuring cylinders & 15 & 78.9 & 10 & 100.0 \\
\hline Ammeters & 8 & 42.1 & 8 & 80.0 \\
\hline Electric motors & 0 & 0 & 2 & 20.0 \\
\hline Mirrors & 11 & 57.9 & 10 & 100.0 \\
\hline Bar breaker & 0 & 0 & 3 & 30.0 \\
\hline Bar and gauge apparatus & 0 & 0 & 3 & 30.0 \\
\hline Triple beam balances & 0 & 0 & 6 & 60.0 \\
\hline Filter funnels & 13 & 68.4 & 10 & 100.0 \\
\hline Gas cylinders & 0 & 0 & 10 & 100.0 \\
\hline Liebig's condenser & 0 & 0 & 6 & 60.0 \\
\hline Test tube holders & 10 & 52.6 & 10 & 100.0 \\
\hline Beakers/boiling tins & 11 & 57.9 & 10 & 100.0 \\
\hline Circuit boards & 4 & 21.1 & 7 & 70.0 \\
\hline Voltmeters & 8 & 42.1 & 5 & 50.0 \\
\hline Solar panels & 0 & 0 & 2 & 20.0 \\
\hline Vacuum flasks & 0 & 0 & 2 & 20.0 \\
\hline Bimetallic strip & 0 & 0 & 6 & 60.0 \\
\hline Spring balance & 11 & 57.9 & 10 & 100.0 \\
\hline Magnets & 15 & 78.9 & 10 & 100.0 \\
\hline Mean & - & 29.9 & - & 62.1 \\
\hline Variance & - & 882.4 & - & 1195.6 \\
\hline
\end{tabular}


Since the 1960's numerous science curriculum development projects had emphasised the value of hands-on, laboratory-based practical work as an enjoyable and effective way of learning science (Hodson,1992). However, the results in Tables 2 and 3 indicate that the rural day secondary schools in the sample were grossly under-resourced. Basic apparatus and chemicals needed for experiments were not available in most of the schools. This observation corroborates the findings of the Report of the Presidential Commission of Inquiry into Education and Training (1999), which noted the same challenge in Zimbabwean secondary schools. In the few schools where apparatus were available, these were not enough especially for group experiments and teachers had to resort to demonstrations most of the time. In some cases where the apparatus were available, there were no chemicals since there were no funds to buy the chemicals and other consumables.

This acute shortage of science teaching and learning materials meant that most of the science concepts were taught theoretically, thereby depriving students of the development of manipulative and other science process skills such as observing, classifying, measuring, inferring, handling apparatus, recording data, interpreting data, drawing conclusions, hypothesizing and reporting on findings. Laboratory work has long been considered the hallmark and a unique feature of science education and, therefore, the unavailability of science equipment and consumables makes science education ineffective. However, the situation is different from that which was found in urban secondary schools that are relatively better resourced. To emphasise the importance of proper and effective science teaching, the Zimbabwean Government has instituted a policy that no school shall be granted Advanced Level status if the school does not have a science laboratory.

\section{Availability of science chemicals and consumables}

Table 2 shows the availability of science chemicals and consumables in rural day and urban secondary schools. The adequacy of the consumables was not determined by the questionnaire but through 
interviews and observations. It could be observed from Table 2 that rural day secondary schools had problems in acquiring relatively expensive consumables such as nitric acid, ammonia, phosphorus, soil indicator, manganese dioxide, mercury, potassium, sodium, ammonium nitrate, bromine, hydrogen peroxide and iodine. However, urban secondary schools seemed to be better resourced than rural day secondary schools as evidenced by a mean of 46.6 for urban schools compared to a mean of 13.1 for rural schools. Since the $t_{\text {calculated }}$ of 6.23 is greater than the $t_{\text {critical }}$ of 2.00 at $p \leq 0.05$, it can be concluded that there is a significant difference in the availability of science consumables between rural secondary schools and urban secondary schools and thus the null hypothesis is rejected. Again, relatively expensive chemicals such as nitric acid, ammonia, soil indicator, manganese dioxide, potassium, sodium, ammonium, bromine, hydrogen peroxide and iodine were not available in any of the 19 rural day secondary schools under study.

Table 2. Availability of science chemicals and consumables in rural day and urban secondary schools

\begin{tabular}{lcccc}
\hline Type of chemical & \multicolumn{2}{c}{ Rural schools $(\mathrm{n}=19)$} & \multicolumn{2}{c}{ Urban schools } \\
& Frequency & $\%$ & Frequency & $\%$ \\
\hline Hydrochloric acid & 2 & 10.5 & 8 & 80.0 \\
Nitric acid & 0 & 0 & 5 & 50.0 \\
Sulphuric acid & 2 & 10.5 & 5 & 50.0 \\
Acetic acid & 4 & 21.1 & 6 & 60.0 \\
Ammonia & 0 & 0 & 4 & 40.0 \\
Sodium hydroxide & 4 & 21.1 & 6 & 60.0 \\
Sodium chloride & 4 & 21.1 & 9 & 90.0 \\
Iron (III) oxide & 4 & 21.1 & 5 & 50.0 \\
Phosphorous & 0 & 0 & 1 & 10.0 \\
Iron filings & 4 & 21.1 & 6 & 60.0 \\
Benedict's solution & 2 & 10.5 & 6 & 60.0 \\
Soil indicator & 0 & 0 & 0 & 0 \\
Calcium oxide & 4 & 21.1 & 6 & 60.0 \\
Glucose & 8 & 42.1 & 7 & 70.0 \\
Iodine solution & 6 & 31.6 & 5 & 50.0 \\
Sulphur & 4 & 21.1 & 6 & 60.0 \\
Manganese dioxide & 0 & 0 & 3 & 30.0 \\
\hline
\end{tabular}




\begin{tabular}{lcccc}
\hline Mercury & 0 & 0 & 0 & 0 \\
Potassium & 0 & 0 & 1 & 10.0 \\
Sodium & 0 & 0 & 1 & 10.0 \\
Copper sulphate & 2 & 10.5 & 5 & 50.0 \\
Ammonium nitrate & 0 & 0 & 6 & 60.0 \\
Bromine & 0 & 0 & 0 & 0 \\
Methylated spirits & 10 & 52.6 & 8 & 80.0 \\
Potassium & 4 & 21.1 & 4 & 40.0 \\
permanganate & & & & \\
Hydrogen peroxide & 0 & 0 & 4 & 40.0 \\
Iodine & 0 & 0 & 4 & 40.0 \\
Filter papers & 4 & 21.1 & 7 & 70.0 \\
Litmus papers & 4 & 21.1 & 7 & 70.0 \\
Mean & - & 13.1 & - & 46.6 \\
Variance & - & 195.4 & - & 644.8 \\
\hline
\end{tabular}

$\mathrm{t}_{\text {calculated }}=6.23 ; \mathrm{t}_{\text {critical }}=2.00$

It could be deduced from Table 2 that rural day secondary schools had problems in acquiring relatively expensive consumables such as nitric acid, ammonia, phosphorus, soil indicator, manganese dioxide, mercury, potassium, sodium, ammonium nitrate, bromine, hydrogen peroxide and iodine. The acute shortage of science chemicals and consumables seem to confirm Nziramasanga's (1999) findings regarding the inadequacy of equipment and books in secondary schools.. However, urban secondary schools seemed to be better resourced than rural day secondary schools as evidenced by a mean of 46.6 for urban schools compared to a mean of 13.1 for rural schools. Since the $t_{\text {calculated }}$ of 6.23 is greater than the $t_{\text {critical }}$ of 2.00 at $p \leq 0.05$, it can be concluded that there is a significant difference in the availability of science consumables between rural secondary schools and urban secondary schools.

\section{Challenges faced by rural day secondary school science teachers}

Table 3 summarises the challenges of teaching and learning science in Zimbabwean rural day secondary schools as perceived by the science teachers in this study. 
Table 3. Challenges faced by rural day secondary school science teachers

\begin{tabular}{cl}
\hline $\begin{array}{c}\text { Item } \\
\text { No. }\end{array}$ & \multicolumn{1}{c}{ Challenges } \\
\hline 1. & $\begin{array}{l}\text { Inadequate teaching and learning } \\
\text { resources }\end{array}$ \\
2. & $\begin{array}{l}\text { Students' negative attitudes towards } \\
\text { science }\end{array}$ \\
3. & $\begin{array}{l}\text { Conflicts between students' home } \\
\text { background and school science }\end{array}$ \\
4. & Absence of science associations. \\
\hline
\end{tabular}

The challenges faced by Zimbabwean rural day secondary schools are shown in Table 3. While all the respondents in this study identified the usual challenges of shortage of teaching and learning facilities, it was encouraging to note that some of the respondents, though few, identified the not so usual but contemporary challenges in science education that are normally experienced by science educators and learners in developing countries.

\section{Students' Negative Attitude towards Science}

Another challenge that was pointed out by $22.7 \%$ of the respondents, as indicated in Table 3, is the students' negative attitude towards science. During the interviews, some respondents pointed out that this negative attitude is normally a result of students viewing science as a very difficult subject. Usually, teachers, who do not use teaching methods that are palatable to students, exacerbate the situation. Kroma (1996) argues that if science and mathematics are to gain popularity, capture the interest of third world pupils and challenge their intellect, the content must be made more appealing by linking it to their immediate experiences and making it relevant to their daily activities. One way to achieve this is through the use of local knowledge as a starting point for the exploration of scientific concepts and inquiry procedures.

Experience has shown that learners tend to understand the concepts taught better when they can relate them to everyday life. Science teachers should, therefore, attempt to contextualize what ever they teach 
by using the learners' environment and experiences as a starting point of their teaching. Focusing on science facts alone may be inadequate for selfknowledge and understanding. Therefore, if students are to learn science meaningfully, they should be able to relate the scientific concepts to their everyday world. This can be done if teachers purposely integrate students' indigenous knowledge with western scientific knowledge.

\section{Conflicts between students' home background and school science}

About $13.6 \%$ of the respondents noted that some students had problems in grasping the scientific concepts taught at school because of the differences between the students' indigenous scientific knowledge and scientific concepts taught at school. The existence of differences between the students' indigenous scientific knowledge and scientific concepts taught at school observation is consistent with some African scholars' suggestions that the African culture and African worldview are impediments to learning science (Chiromo, 2004; Ogunniyi, 2004). It was suggested that the impediments were associated with the fact that many students in developing countries perceived science studies like a foreign culture to them (Ogawa 2004). This foreignness might arise from differences between students' life world cultures, and the culture generally advocated by the scientific community (Lee, 2003).

This cultural conflict observed observation by $13.6 \%$ of the teachers corroborates the previous findings (Aikenhead, 2001; Lee, 2003) who posited that school-based concepts might conflict with students' everyday beliefs, hence learning some science concepts would require students to develop strategies for crossing cultural borders from their everyday sub-cultures of peers, family and ethnic group to the subculture of science.

In an earlier study, Phelan et al. (1991) explored how students moved from one culture to another. Their data suggested four types of transitions: congruent cultures support smooth transitions; different cultures require transitions to be managed; diverse cultures lead to hazardous transitions and highly discordant cultures cause students to resist transitions, which therefore become virtually impossible. In another related study, Costa (1995) categorised 
students into four groups depending on how students crossed cultural borders. Firstly there were "potential scientists," who crossed the borders smoothly and enjoyed the challenges of the academic science subject matter, and persevered even with bad teaching. The second group consisted of the "other smart kids," who managed the border crossing and did well in school, although school science might be neither personally meaningful, nor useful to their everyday lives. The third group was the "I don't know students," who tended to play "Fatima's rules". Fatima's rules are associated with a game in which students learn to pass examinations without understanding the main concepts (Larson, 1995), resulting in hazardous border crossing.

The last group comprised the "outsiders," who found the borders virtually impossible to cross, and were likely to drop out of school. The last three categories would require teachers to act as cultural brokers, who would assist students to move back and forth between their indigenous culture and the culture of western science. In this situation, teachers would be expected to help such students to deal with cultural conflicts that might arise (Aikenhead and Jegede, 1999). Success in science, therefore, could depend on how effectively students moved between their life world and the culture of science.

\section{Absence of science teachers' associations}

Table 3 shows that the majority $(68.2 \%)$ of the respondents in the study bemoaned the absence of science teachers' associations in their district. Under normal circumstances, science teachers' associations would spearhead the staff development of science teachers on contemporary issues in science education. By attending staff development workshops or seminars organised by these science teachers' associations, teachers would get a chance to interact and share ideas with colleagues. However, some efforts have been made since Zimbabwean independence in 1980 to improve the teaching of science, especially at secondary school level. Programmes such as the Zim-Sci project was introduced in 1981 with a view of improving the teaching of science particularly in rural secondary schools. The Quality Education in Science Teaching (QUEST) project was 
also designed to cater for secondary science education. The Science Education In-service Teacher Training (SEITT) programme was introduced as a staff development organ, which caters for "A" level science and mathematics teachers. It should be noted that all these programmes referred to above were donor funded hence their sustainability depended on the good will of the donors who eventually withdrew their sponsorship. There is need, therefore, to establish vibrant science teachers' associations to spearhead the development of science education not only in Gweru district but the whole country.

\section{Conclusion}

The study established that rural day secondary school science teachers face a number of challenges, including inadequate teaching and learning materials, students' negative attitudes towards science, conflicts between students' home background and school science, and absence of science teachers' associations. These challenges could have a direct impact on the teaching and learning of science in rural day secondary schools. The study recommends the following to address some of these challenges: teachers should be innovative and improvise science teaching and learning material where possible, instead of waiting for conventional apparatus. Teachers should also act as cultural brokers to resolve conflicts between students' home background and school science by using students' local and indigenous knowledge as a starting point for the exploration of scientific concepts. Science associations, in which science teachers could share ideas on contemporary issues in science teaching and learning, should be revived.

\section{Bibliography}

Aikenhead, G. S. (2001). Integrating Western and Aboriginal sciences: Cross-cultural science teaching. Research in Science Education 31 (3): 327-335. 
Aikenhead, G. S. and Jegede, O. J. (1999). Cross-cultural science education: A cognitive explanation of a cultural phenomenon. Journal of Research in Science Teaching 35 (2): 337-355.

Chiromo, A. S. (2004). Effects of socio-cultural beliefs on science education in Zimbabwe: Implications for science teaching. INDILINGA: African Journal of indigenous knowledge systems 32: 126-133.

Costa, V. B. (1995). When science is "another world": Relationships between worlds of family, friends, school and science. Science Education 79: 313-333.

Hodson, D. (1992). Assessment of practical work: Some considerations in Philosophy of Science. Science and Education 1: 115-144.

Hungwe, K. (1994). A decade of science education in Zimbabwe (19801990): Nationalist vision and post-colonial realities. Journal of Curriculum Studies 20 (1): 83-95.

Kroma, S. (1996). Popularising science education in developing countries through indigenous knowledge. http://www. A; \IK Monitor 3(3) Kroma. htm. 18/01/06.

Larson, J. O. (1995). Fatima's rules and other elements of an unintended chemistry curriculum. Paper presented at the American Educational Research Association annual meeting, 16 April 1995. San Francisco, USA.

Lee, O. (2003). Equity for culturally and linguistically diverse students in science education: A research agenda. Teachers College Record 105 (3): 465-489.

Lvina, E. (2015). The Role of Cross-Cultural Communication Competence: Effective Transformational Leadership Across Cultures. Jurnal Ilmiah Peuradeun, 3(1), 1-18.

Ministry of Education and Culture. (1995). Ministry of Education Secretary's Report (1981-1995), Harare, Zimbabwe. . (2000). Integrated Science Syllabus 5006, Harare, Zimbabwe.

Nziramasanga, C. (1999). Report of the Presidential Commission on Education and Training. Harare, Zimbabwe.

Ogawa, M. (2004). Origin, structure and nature of indigenous science and "Seigyo" (subsistence). A paper presented to the annual conference 
of the National Association for research in science teaching, Vancouver, Canada, 24 April 2004.

Ogunniyi, M. B. (2004). The challenge of preparing and equipping science teachers in higher education to integrate scientific and indigenous knowledge systems for their learners. South African Journal of Higher Education 18(3): 289-304.

Phelan, P., Davidson, A., and Cao, H. (1991). Students' multiple worlds: Negotiating the boundaries of family, peer and school cultures. Anthropology and Education Quarterly 22: 224-250.

Ross, K. (1998) (Ed.). Southern Africa Council of Ministers of Education Policy Research: Report No. 3. Ministry of Education and Culture, Harare, Zimbabwe.

Safrina, S., \& Saminan, S. (2015). The Effect of Model Problem Based Learning (PBL). Jurnal Ilmiah Peuradeun, 3(2), 311-322.

Sulaiman. (2015). Classroom Management and the Implications to Quality of Learning (A Study About Classroom Climate at Madrasah Aliyah in Aceh, Indonesia). Jurnal Ilmiah Peuradeun, 3 (3), 431-440.

Zimbabwe Schools Examinations Council Report, 1995-2005. (2005). Harare, Zimbabwe. 